\title{
Ostwald solubility coefficients of some industrially important substances
}

\author{
R. J. SHERWOOD \\ Colt International Ltd, Havant, Hampshire
}

\begin{abstract}
Sherwood, R. J. (1976). British Journal of Industrial Medicine, 33, 106-107. Ostwald solubility coefficients of some industrially important substances. Solubility coefficients in blood for benzene, toluene, and xylene were determined as $6.5,16$, and 42 respectively. In lard and olive oil, which were taken to represent human fat, corresponding values were about 450 , 1300 , and 3900 . The coefficient for vinyl chloride in lard and olive oil was 20 ; the value in blood was too low to be determined by the technique used. Trichloroethylene, used as a marker, was found to have a coefficient in lard of 660 , and in olive oil of 710 , rather lower values than have been accepted for fat.
\end{abstract}

To study uptake and elimination of anaesthetic gases, analogue computer models of the processes in the body have been developed (Mapleson, 1963), and have been used for assessing occupational exposures (Fiserova-Bergerova and Cettl, 1972). Recently, refinements have been made to such models, and these have been adapted to digital computing methods (Mapleson, 1973; FiserovaBergerova, Vlach, and Singhal, 1974). However, mathematical modelling of metabolic processes, such as the production of phenol in urine after exposure to benzene, has not yet been achieved.

Essential to such modelling is a knowledge of Ostwald solubility coefficients as these define the partitioning of dissolved vapour between the different compartments of the body. Recently, a compendium of known determinations was published (Steward et al., 1973) but this excluded the aromatic hydrocarbons that are of industrial importance. To provide information for the mathematical modelling of experimental exposures (Sherwood, 1972a) some new determinations of partition coefficients have been made and are reported here.

\section{Method}

After some preliminary determinations of vapour concentrations over human blood and oil containing known amounts of benzene (Sherwood, 1972b), a more definitive series of measurements was made using the gas chromatographic technique described by Lowe and Hagler (1969).
To represent human fat, chromatographic columns were prepared which comprised either $65 \mathrm{mg}$ lard or $70 \mathrm{mg}$ olive oil adsorbed on about 4.5 g M \& B Embacel support (120-150 mesh, acid-washed kieselguhr) in $91.5 \mathrm{~cm} \times 6.4$ mm PTFE.

The columns were maintained at a constant temperature of $37^{\circ} \mathrm{C}$ with a nitrogen carrier gas flow of about 53 $\mathrm{ml} / \mathrm{min}$. A flame ionization detector was used, and methane and trichloroethylene were used as markers.

Some difficulties were met in adsorbing the blood sample on the Embacel support and in obtaining sharp peaks. It was found essential to saturate the nitrogen with water vapour at room temperature to maintain the condition of the blood. Because the water content was variable, the precise loading of blood was not known.

\section{Results}

Absolute values of the solubility coefficients $(K)$ for lard and olive oil were determined from the equations used by Lowe and Hagler (1969):

$K=\frac{\left(V_{R}^{0}-V_{G}^{0}\right) \rho_{L}}{W_{L}}$

where $V_{R^{0}}{ }^{0}=$ gas retention volume

$V_{G}{ }^{0}=$ retention volume of inert marker

$\rho_{L}=$ density of lard or olive oil at column temperature

$W_{L}=$ weight of lard or olive oil on column

and

$\mathrm{V}_{R}{ }^{0}=1 \cdot 5 t_{R} F_{C}\left[\frac{\left(P_{1} / P_{0}\right)^{2}-1}{\left(P_{1} / P_{0}\right)^{3}-1}\right]$

where $t_{R}=$ time from injection to peak height

$F_{C}=$ carrier gas flow 
TABLE

Results for Five Substances and MARKer

\begin{tabular}{|c|c|c|c|c|c|c|c|c|}
\hline \multirow{3}{*}{\multicolumn{2}{|c|}{ Substance }} & & \multicolumn{6}{|c|}{ Ostwald solubility coefficients } \\
\hline & & & \multicolumn{2}{|c|}{ Blood } & \multicolumn{2}{|c|}{ Lard } & \multicolumn{2}{|c|}{ Olive oil } \\
\hline & & & $\begin{array}{l}\text { Relative to } \\
\text { TCE }\end{array}$ & Absolute & $\begin{array}{l}\text { Relative to } \\
\text { TCE }\end{array}$ & Absolute & $\begin{array}{l}\text { Relative to } \\
\text { TCE }\end{array}$ & Absolute \\
\hline \multicolumn{2}{|c|}{ Trichloroethylene (TCE) } & .. & 1.00 & $9 \cdot 0$ & 1.00 & 656 & 1.00 & 714 \\
\hline \multirow{2}{*}{$\begin{array}{l}\text { Vinyl chloride } \\
\text { Chloroform }\end{array}$} & .. & .. & - & $\overline{0}$ & 0.030 & 20 & 0.028 & 20 \\
\hline & .. & .. & 0.91 & $8 \cdot 2$ & & & & \\
\hline Benzene & .. & .. & 0.71 & $6 \cdot 5$ & 0.65 & 424 & 0.65 & 461 \\
\hline Toluene & $\ldots$ & .. & $1 \cdot 71$ & $15 \cdot 6$ & 1.94 & 1270 & 1.93 & 1380 \\
\hline Xylene.. & & .. & 4.63 & $42 \cdot 1$ & 5.74 & 3760 & 5.68 & 4050 \\
\hline
\end{tabular}

$P_{\mathbf{i}}=$ absolute pressure at column inlet

$P_{0}=$ absolute pressure at column outlet. Absolute values for blood could not be determined directly as $W_{L}$ was unknown. They were deduced from the retention times relative to trichloroethylene, for which an absolute value of $\mathbf{9 . 0}$ was assumed (Steward et al., 1973).

The results for five substances are shown in the Table.

\section{Comment}

The solubility coefficients for the aromatic hydrocarbons increase with molecular weight, and no great differences are seen between those in lard and olive oil, so human fat is probably well represented. The ratios between the coefficients for the aromatic hydrocarbons and trichloroethylene in lard and oil are consistent with those in blood.

The check measurement of the solubility coefficient of chloroform in blood (8.2) is effectively identical with the recommended value of 8.0 (Steward $e t$ al., 1973). The absolute values for trichloroethylene of 656 in lard, and 714 in olive oil, are lower than the recommended value of 943 derived from measurements in soya bean oil by Soucek (1955), but in close agreement with that of Lowe and Hagler (1969) who reported 634 and 740 in human fat.

The values for benzene are lower than the preliminary values reported (Sherwood, 1972a) which corresponded to $9 \cdot 2$ for blood, and 890 for fat. That for benzene in blood is in close agreement with the values of 6.58 derived by Schrenk et al. (1941) for dogs, and of 7.76 determined by Teisinger and Skramovsky (1947) for man.

This work was undertaken while the author was with Esso Europe Inc. Grateful acknowledgement is made to Mr F. W. G. Carter of Esso Research Centre, Abingdon, for undertaking the gas chromatographic measurements, and to Professor W. W. Mapleson of the Welsh National School of Medicine for helpful discussions.

\section{References}

Fiserova-Bergerova, V. and Cettl, L. (1972). Electric analogue for uptake, metabolism, and excretion of lipid soluble solvents in man (in Czechoslovakian). Pracovni lekarstvi, 24, 56-61.

_ , Vlach, J., and Singhal, K. (1974). Simulation and prediction of uptake, distribution, and exhalation of organic solvents. British Journal of Industrial Medicine, 31, 45-52.

Lowe, H. J. and Hagler, K. (1969). In Gas Chromatography in Biology and Medicine, edited by R. Porter, pp. 86-112. Churchill, London.

Mapleson, W. W. (1963). An electric analogue for uptake and exchange of inert gases and other agents. Journal of Applied Physiology, 18, 197-204.

- (1973). Circulation-time models of the uptake of inhaled anaesthetics and data for quantifying them. British Journal of Anaesthesia, 45, 319-334.

Schrenk, H. H., Yant, W. P., Pearce, S. J., Patty, F. A., and Sayers, R. R. (1941). Absorption, distribution and elimination of benzene by body tissues and fluids of dogs exposed to benzene vapor. Journal of Industrial Hygiene and Toxicology, 23, 20-34.

Sherwood, R. J. (1972a). Comparative methods of biologic monitoring of benzene exposure. In Proceedings of the 3rd Annual Conference on Environmental Toxicology, AMRL-TR-130. Aerospace Medical Research Laboratory, Wright Patterson Air Force Base, Ohio, USA. (1972b). Benzene: the interpretation of monitoring results. Annals of Occupational Hygiene, 15, 409-423.

Soucek, B. (1955). Distribution coefficient of trichloroethylene (in Czechoslovakian). Pracovni lekarstvi, 7, 86.

Steward, A., Allott, P. R., Cowles, A. L., and Mapleson, W. W. (1973). Solubility coefficients for inhaled anaesthetics for water, oil, and biological media. British Journal of Anaesthesia, 45, 282-293.

Teisinger, J. and Skramovsky, St. (1947). Sur la courbe de saturation du benzène dans le sang. Archives des Maladies Professionales de Medicine del Travail et de Sécurité Sociale, 8, 257-261.

Received for publication 9 April 1975

Accepted for publication 13 January 1976 